P-ISSN: 2774-4574; E-ISSN: 2774-4582 TRILOGI, 2(1), Januari-April 2021 (71-80) @2021 Lembaga Penerbitan, Penelitian, dan Pengabdian kepada Masyarakat (LP3M) Universitas Nurul Jadid Paiton Probolinggo DOI: https://doi.org/

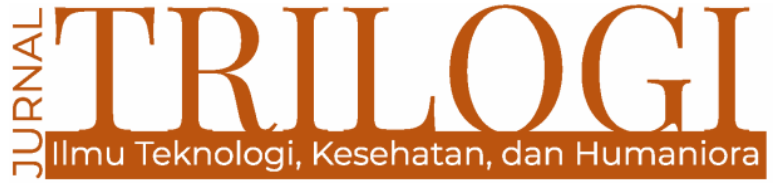

\title{
ISLAMIC STUDIES DALAM KONTEKS GLOBAL DAN PERKEMBANGANYA DI INDONESIA
}

\author{
Muhammad Nadiddin Al Hanif
}

Sekolah Tinggi Agama Islam Istiqlal, Buleleng, Bali

nadiddin.hanif189@gmail.com

\begin{abstract}
This article discusses about history of Islamic studies in global context and its developments in Indonesia. The deep problem in this paper is about the roots of tradition of Islamic studies at educational institutions in Indonesia. Besides, this paper also intends to explore the influence of the West against toward Islamic studies in Indonesia. This paper is a literature review where the historical approach was used to investigate it. Based on the discussion, it could be summarized that the Islamic studies can not be separated from the Orientalism on the context of history and also it included the history of Christianity. Since, the reality of Orientalism closes and interacts directly with the program of imperialism as well, especially both Asia and Africa. In fact, many Islamic countries are in Eastern parts of the universe. In Indonesia, Islamic Studies had long existed and become an important study, because it has become a necessity for Moslems, especially in the academic context which is learned in UIN, IAIN, and STAIN. A number of Indonesian Moslem scholars who studied in Western have implicated on thier style also method of islamic study in Indonesia.
\end{abstract}

Keywords: Islamic Studies; Contemporary; Western; and Orientalism

\begin{abstract}
Abstrak
Artikel ini membahas tentang kajian Islam dalam lintas sejarah dalam konteks global dan perkembangannya di Indonesia. Permasalahan mendasar dalam kajian ini adalah mengenai akar tradisi studi Islam pada lembaga pendidikan di Indonesia. Selain itu, tulisan ini juga bermaksud menelusuri pengaruh Barat terhadap studi Islam di Indonesia. Kajian dalam tulisan ini merupakan kajian pustaka dengan pendekatan historis. Berdasarkan pembahasan yang telah dilakukan dapat disimpulkan bahwa Studi Islam tidak dapat dipisahkan dari Orientalisme dalam konteks sejarah dan termasuk sejarah agama Kristen, sebab secara realitas orientalisme lebih dekat dan bersinggungan langsung dengan program imperialisme khususnya di Asia dan Afrika, dan dalam kenyataannya banyak Negara Islam berada di bagian Timur belahan dunia. Di Indonesia, Studi Islam telah lama ada dan menjadi studi yang penting, dikarenakan telah menjadi kebutuhan bagi umat Islam terutama dalam konteks akademik seperti yang dipelajari di UIN, IAIN, dan STAIN. Banyaknya intelektual muslim Indonesia yang studi di negara-negara Barat berimplikasi pada corak dan metode studi Islam di Indonesia.
\end{abstract}

Katakunci: Studi Islam; Kontemporer; Barat; dan Orientazlisme. 


\section{Pendahuluan}

Pengkajian Islam (Islamic Studies) atau Studi Islam, termasuk bidang studi yang sudah cukup tua serta sudah lama berkembang dan menjadi salah satu disiplin ilmu yang berkembang cukup pesat pada abad ke 20 M, bahkan secara embrional disiplin studi Islam tersebut telah dirintis sejak abad-abad ke 13 M, setelah Perang Salib. Studi terhadap Islam awalnya dilakukan oleh orang Barat untuk meneliti ajaran Islam melalui studi orientalisme. Pada dasarnya ada beberapa teori tentang perkembangan disiplin ilmu ini, di antaranya karena konektifitas Islamic Studies dengan studi orientalisme yang digagas oleh para ilmuwan Barat dan disponsori oleh penguasa Barat pada era kolonialisme Barat atas bangsa Timur, untuk mempelajari agama serta budaya ketimuran oleh penguasa kolonial dalam rangka menaklukkan Timur, serta dalam rangka melanggengkan kekuasaan mereka terhadap negara-negara di kawasan Timur terutama bangsa-bangsa Asia, lebih dari itu studi orientalisme juga sarat dengan kepentingan terselubung yakni penyebaran agama Kristen. Istilah Islamic Studies atau kemudian di kenal dengan istilah "Dirasah Islamiyah" atau "Studi Islam". (Abdul Kadir Riyadi, 2019)

Sejak awal abad ke-20 banyak sarjana muslim yang berguru ke Barat untuk mempelajari Islam dari kacamata Barat, di berbagai universitas yang ada di Eropa maupun di Amerika. Pada umumnya kajian tentang Islam diajarkan oleh tokoh-tokoh Orientalis yang ahli di bidang ilmu ketimuran atau bahkan ahli tentang agama Islam secara mendalam, walaupun secara realitas mereka tidak memeluk agama Islam. Para alumni universitas Barat yang mengambil Studi Pengkajian Islam (Islamic Studies) tersebut kemudian kembali ke tanah air dengan mengembangkan ilmu yang diperolehnya dan diajarkan di berbagai universitas atau institut yang ada di Indonesia. Pada umumnya kajian Islam (Islamic Studies/Dirasah Islamiyah) lebih banyak dilakukan di IAIN, karena sebagian dosen-dosenya adalah alumni dari Universitas di Barat, seperti Universitas Mc Gill Kanada, Universitas Sorbone Perancis, Universitas Leiden Belanda, Universitas California Amerika Serikat, Universitas Chicago Amerika Serikat dan sebagainya. (Amin Abdullah, 2017)

Barangkali puncak perkembangan Pengkajian Islam (Islamic Studies) di Indonesia terjadi pada tahun 1980 an hingga akhir 1990 an, yang ditandai oleh maraknya kajian Islam yang dimotori oleh sejumlah akademisi dan munculnya beberapa intelektual muslim Indonesia, alumni Barat yang banyak melontarkan gagasan pembaruan pemikiran Islam. Fenomena tersebut sesungguhnya bukan hanya terjadi di Indonesia saja tetapi sudah menjadi fenomena global, yang dapat ditemukan di berbagai negara baik mayoritas penduduknya beragama Islam ataupun di beberapa negara Barat seperti di Amerika, Inggris, Perancis, Kanada, Jerman Balanda, dan lain sebagainya. Bagaimana sebenarnya perkembangan Islamic Studies secara global dan realitas pelaksanaanya Indonesia, akan dikupas secara deskriptif dalam tulisan ini.

\section{Metode}

Penelitian ini menggunakan pendekatan kualitatif, yaitu mendeskripsikan dan menguraikan tentang pengaruh penggunaan media pembelajaran dalam dunia pendidikan. Teknik pengumpulan data yang digunakan dalam penelitian ini adalah studi kepustakaan (Library Research) dimana studi kepustakaan adalah kegiatan mengumpulkan bahan-bahan yang berkaitan dengan penelitian yang berasal dari buku, jurnal-jurnal ilmiah, literatur-literatur dan publikasi-publikasi lain yang layak dijadikan sumber untuk penelitian yang akan di teliti penulis, dengan cara mendeskripsikan dan menguraikan data tersebut adalah melalui beberapa pendapat para ahli. (Suharsimi Arikunto, 2010) Variabel penelitian adalah segala sesuatu yang berbentuk apa saja yang ditetapkan oleh peneliti untuk dipelajari sehingga diperoleh informasi tentang hal tersebut kemudian ditarik kesimpulannya. Variabel yang digunakan dalam penelitian adalah Variabel Bebas (Independent Variable) dan Variabel Terikat (Dependent Variable). Maka dengan menggunakan pendekatan kualitatif penelitian ini diharapkan bisa memberikan fakta-fakta secara komprehensif tentang pengaruh penggunaan media pembelajaran dalam dunia pendidikan. Manfaat dari penulisan ini adalah untuk menambah wawasan bagi para pembaca mengenai pentingnya media pembelajaran dalam dunia pendidikan.

\section{Hasil dan Pembahasan}

Pada hakikatnya, studi Islam (islamic studies) merupakan bidang kajian yang menempatkan Islam sebagai objek penelitian. Dalam hal ini, AlQuran sebenarnya telah menjelaskan pentingnya 
studi Islam ini dalam dalil-dalil yang mengarah pada urgensi riset dalam kehidupan manusia. Dalil-dalil tersebut antara lain sebagai berikut

a. QS Al-Hasyr ayat 18

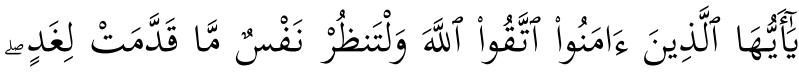

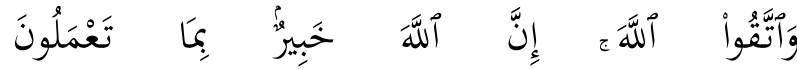

Artinya: "Hai orang-orang yang beriman, bertakwalah kepada Allah dan hendaklah setiap diri memperhatikan apa yang telah diperbuatnya untuk hari esok (akhirat); dan bertakwalah kepada Allah, sesungguhnya Allah Maha Mengetahui apa yang kamu kerjakan" (Al-Hasyr: 18)

b. QS Al-Hujurat ayat 6

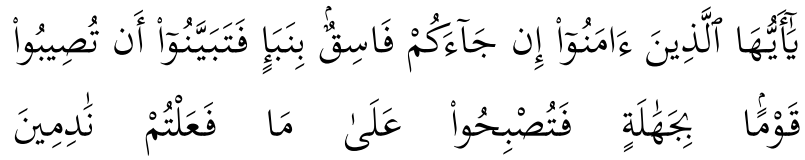

Artinya: "Hai orang-orang yang beriman, jika datang kepadamu orang fasik membawa suatu berita, maka periksalah dengan teliti agar kamu tidak menimpakan suatu musibah kepada suatu kaum tanpa mengetahui keadaannya yang menyebabkan kamu menyesal atas perbuatanmu itu" (Al-Hujurat: 6)

C. QS. Maryam ayat 84

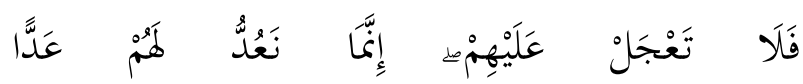

Artinya:"Maka janganlah kamu tergesa-gesa memintakan siksa terhadap mereka, karena sesungguhnya Kami hanya menghitung datangnya (hari siksaan) untuk mereka dengan perhitungan yang teliti" (Maryam: 84)

\section{d. QS Shaad ayat 29}

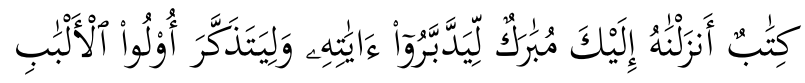
Artinya:"Ini adalah sebuah kitab yang Kami turunkan kepadamu penuh dengan berkah supaya mereka memperhatikan ayat-ayatNya dan supaya mendapat pelajaran orang-orang yang mempunyai fikiran". (Shaad: 29)

\section{e. QS An-Nisa' ayat 7}

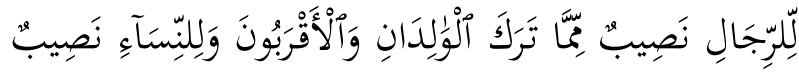

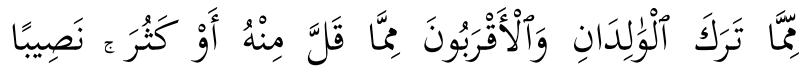

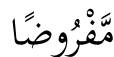

Artinya: "Bagi orang laki-laki ada hak bagian dari harta peninggalan ibu-bapa dan kerabatnya, dan bagi orang wanita ada hak bagian (pula) dari harta peninggalan ibu-bapa dan kerabatnya, baik sedikit atau banyak menurut bahagian yang telah ditetapkan". (an-Nisa': 7)

Adapun sumber-sumber ilmu dalam studi Islam ada empat macam, yaitu: Pertama, panca indera (al-hawas al-khams) dalam bentuk indera pendengar (as-sam), indera pelihat (al-bashar), indera pencium (asy-syamm), indera perasa (azzauq), dan indera peraba atau penyentuh (allams). Kedua, akal atau nalar atau pikir yang dimanfaatkan dalam proses pencarian ilmu. Ketiga, intuisi hati ( $q a / b)$ atau Ilham, yang merupakan sumber ilmu bersifat batin yang berkaitan dengan hati dan jiwa seseorang dalam memberikan sesuatu pengetahuan. (Richard C. Martin, 1995) Keempat, al-khabar ash-shadiq atau informasi yang benar, yang berasal dari dan bersandar pada otoritas tertentu, berupa Kitab Suci atau Sunnah Nabi).

Bangunan ilmu dalam studi Islam adalah suatu bangunan ilmu yang terdiri dari tiga unsur pokok, yaitu: Pertama, unsur yang disebut dengan 'ilm al-wujud, yaitu sesuatu yang dapat dijadikan sebagai objek pengamatan dan penelitian, melalui indera atau akal atau lainnya. Dalam kajian filsafat ilmu unsur ini sering dikenal dengan ontologi. Berbeda dari pemikir Barat modern yang hanya menjadikan fisika sebagai yang dapat diobservasi atau sebagai objek pengetahuan dan penelitian, para pemikir Muslim memandang bahwa objek penelitian, bukan hanya fisika, melainkan juga nash-nash (ayat Al-Qur`an dan hadits), dan metafisika. Kedua, unsur yang disebut dengan nazhariyah al-ma'rifah, yaitu teori-teori dan caracara mendapat atau menemukan pengetahuan, yang dalam kajian filsafat ilmu sering dikenal dengan epistemologi. Berbeda dari para pemikir Barat modern, para pemikir Islam mengatakan bahwa epistemologi Islam yang dapat digunakan dalam penelitian dan pengembangan pengetahuan adalah: membaca, berpikir, eksperimen, penelitian, observasi, dan attaqarrub ila Allah. Ketiga, unsur yang disebutl 'ilm al-'amal, yang dalam kajian filsafat ilmu disebut dengan aksiologi. Dalam studi Islam, selain dua hal di atas, bangunan penting dari suatu ilmu adalah 'ilm al-'amal, yaitu aspek praktek dan aktualisasi dari suatu ilmu yang telah didapatkan melalui berbagai epistemologi di atas.

Selanjutnya, studi Islam tidaklah meletakan ilmu itu dalam kerangka dikotomis. Yang membedakannya adalah nilai-nilai manfaat dan maslahat. Munculnya pemikiran yang diklaim sebagai paham dikotomis ilmu agamawi dan duniawi, secara historis, tampaknya salah satu konsekuensi dari era disintegrasi. Kelanjutannya, muncul statemen bahwa ilmu yang agamawi (ilmu-ilmu agama) harus mendapat perhatian yang lebih ketimbang ilmu yang duniawi (ilmuilmu dunia). Kemudian, pahala ilmu agamawi dipandang lebih banyak dibanding ilmu-ilmu duniawi. Statemen dan pandangan semacam ini tentu saja tidak memiliki dasar pijakan atau dalil yang jelas.

Metode-metode penelitian dalam studi Islam ada empat macam. Pertama, metode bayani yaitu 
suatu metode penelitian untuk menemukan ilmu, dengan melalui usaha maksimal membaca, memahami, mempelajari dan mengkaji penjelasan-penjelasan dari nash-nash Al-Qur`an dan Sunah untuk menangkap pesan-pesan yang terdapat di dalamnya. Kedua, metode burhani adalah suatu metode penelitian atau penemuan ilmu yang mengandalkan kemampuan berpikir logis, dengan kaidah-kaidah tertentu yang disusun secara runtut dan sistematis.

Umpamanya dengan menggunakan prosedur silogisme, yaitu: al-muqaddimah al-kubra (premis mayor) dan al-muqaddimah ash-shughra (premis minor), al-hadd al-wasath (middel term = kata yang berulang) dan an-natijah (konklusi = kesimpulan). Ketiga, metode tajribi yaitu suatu metode penelitian atau penemuan ilmu yang, selain memerankan kemampuan berpikir logis, juga dilanjutkan dengan tindakan eksperimen, observasi atau bentuk-bentuk metode yang dikenal dalam metode penelitian ilmiah sekarang ini. Keempat, metode 'irfani yaitu suatu metode penelitian atau penemuan ilmu yang mengandalkan at-taqartub ila Allah atau al-Ittishal bi al-ilahi, dengan melakukan langkah-langkah tertentu, mulai dari tindakan persiapan-persiapan (isti'dad), dalam bentuk tazkiyah an-nafs (membersihkan diri dari segala kekotoran jiwa) dalam rangka menyambut sinar kebenaran yang hadir secara langsung ke dalam hati, tanpa melalui simbol dan atau presentasi. Teknik dalam metode 'irfani ini adalah dengan melakukan riyadhah, yaitu latihan-latihan dalam arti melakukan amalan-amalan secara terus menerus dengan cara-cara tertentu. Umpamanya, dengan melakukan secara rutin hal-hal sebagai berikut: membaca Al-Qur'an, wirid-wirid dengan asma' al-husna, tasbih, tahmid, takbir, tahlil, hauqalah, shalawat, baik secara individu maupun secara kelompok dengan mengikuti mursyid, seperti terlihat dalam berbagai kelompok thariqat.

Mengenai produk-produk ilmu, sepanjang sejarah peradaban Islam, secara garis besar, ada tiga macam produk ilmu atau pengetahuan yang beredar di kalangan kaum muslimin, yaitu: Pertama, Produk ilmu yang dikenal dengan istilah al-'ilm at-ta'limi atau al-'ilm al-bayani. Produk ilmu semacam ini dihasilkan oleh metode bayani, melalui usaha maksimal dalam memahami, mengkaji dan mempelajari penjelasan-penjelasan dari nash-nash atau teks-teks Al-Qur`an dan Sunnah. Produk al-'ilm at-ta'limi ada yang sifatntya teoritis, seperti ulum al-Qur'an, 'ulum al-hadits, 'ushul al-fiqh dan 'ilm mantiq, dan ada yang sifatnya praktis ('amaliyah), seperti ilmu fiqih, ilmu kalam, dan lain-lain. Kedua, Produk ilmu yang disebut dengan al-'ilm at-tahshili atau al-'ilm al-hushuli, yaitu ilmu yang dihasilkan oleh metode tajribi atau metode 'ilmiyah, yaitu ilmuilmu yang masuk dalam kategori natural sciences, seperti ilmu kedokteran dan social scinces, seprti ilmu ekonomi Islam. Ketiga, Produk ilmu yang disebut dengan al-'ilm al-hudhuri atau al-'ilm at-tahdhiri atau al-'ilm al-ladunni. Yaitu ilmu yang dihasilkan melalui pendekatan diri kepada Allah (at-taqarrub ila Allah) atau berhubungan langsung dengan Tuhan (al-ittishal ila al-Ilah). Produk ilmu yang masuk dalam kategori ini, dihasilkan melalui metode 'irfani, dengan langkah- langkah tertentu, mulai dari melakukan tindakan persiapan-persiapan (isti'dad), dalam bentuk tazkiyah an-nafs (membersihkan diri dari segala kekotoran jiwa) dalam rangka menyambut sinar kebenaran yang langsung hadir ke dalam hati, tanpa melalui simbol dan atau presentasi. Dengan ungkapan dan pemahaman yang lebih sederhana, produk ilmu ini adalah apa yang dikenal dengan ilmu tasawuf, baik tasawuf akhlaqi, tasawuf 'amali dan tasawuf falsafKajian keislaman dalam konteks tradisi akademik Barat bukan sesuatu yang baru, karena tradisi kajian keislaman ala Barat berakar pada sejarah yang sangat panjang. Paling tidak sejauh hubungan Kristen dengan Islam. Tidak dapat dielakkan bahwa sebab utama dari pertumbuhan Kajian Keislaman (Islamic Studies) adalah karena alasan teologis untuk menunjukkan dan mempertahankan keabsahan ajaran Kristen, dibandingkan dengan Islam. Bagi kalangan misionaris, hasil kajian keislaman itu digunakan untuk mengefektifkan tugas-tugas penyebaran Kristen khususnya ke wilayah-wilayah yang didominasi. Sebelum menjadi lapangan kajian disiplin akademik, tradisi kajian keislaman itu memang lebih bersifat politik dalam usaha mempertahankan dan meningkatkan dominasi Barat atas wilayah Islam. Dalam konteks ini perkembangan Islamic Studies, mempunyai dua alasan utama yakni dalam konteks politis dan dalam konteks misionari agama Kristen, artinya Islamic Studies muncul sebagai bagian dari kebijakan politis pemerintah kolonial untuk memperbesar kekuasaannya sekaligus untuk melancarkan program Kristenisasi di wilayah jajjahannya, seperti politik pemerintah Hindia Belanda, yang mengangkat C. Snouck Hurgronje, seorang ahli Islam, sebagai penasehat politik pemerintah untuk menundukkan daerah jajahannya. Pada awal abad ke-19 Islamic Studies mulai berkembang sebagai bagian dari kajian masalah-masalah ketimuran (orientalisme atau oriental studies), dan baru pada paruh kedua dari abad ke-20, ada upaya kuat untuk memisahkan dari atau tidak mengidentikkannya-antara Islamic Studies dan Oriental Studies-sebagai disiplin yang berbeda, walaupun tetap saja sangat sulit pada awalnya memisahkan antara Islamic Studies disatu sisi dan upaya kajian orientalisme di lain sisi. Paling tidak akar-akar sejarah 
pertumbuhan dan perkembangan kajian keislaman ala Barat dapat diidentifikasi dalam tiga tahap yaitu tahap teologis, tahap politis dan tahap saintis. (Affandi Mochtar, 2001)

Pertama, tahap teologis dapat dilacak sejak abad awal Islam di mana kemunculan dan kedatangannya mendapat respon langsung dari pemeluk agama lainnya termasuk Kristen. Reaksi ini kemudian menstimulir lahirnya berbagai kajian Islam oleh pemeluk Kristen, sebagai agaman yang telah benkembang lebih dahulu di kalangan Bangsa Arab. Kesimpulan St John menganggap bahwa Islam sebagai ajaran murtad (Christian Heresy), dan dalam karyanya yang berjudul Dispution Beetwen a Saracen and a Christian, St John menujukkan sikap teologisnya yang tidak mengakui kenabian Muhammad. Pandangan St John tetap dikuti oleh kalangan gereja pada beberapa abad sesudahnya, kabanyakan mereka mengingkari ajaran Islam dengan tanpa pengetahuan yang cukup. (Affandi Mochtar, 2001)

Kedua, pada abad ke-12 ketika terjadi Perang Suci/Perang Salib, Kajian Keislaman (Islamic Studies) dilakukan dengan tujuan politik sekaligus misionaris, kombinasi tujuan mempelajari Islam tersebut tidak bisa dilepaskan dari upaya menghadapi peradaban Islam. Richard C. Martin melukiskan kondisi ini sebagai "perang suci dan penerjemahan al-Qur'an dan teks-teks Muslim lain kedua-duanya merupakan langkah serangan terhadap peradaban Islam yang berada di pebatasan bagian selatan dan timur wilayah Kristen Barat". Tokoh-tokoh yang muncul pada periode ini adalah Peter de Venerable (1094-1156) dianggap sebagai pemrakarsa tentang kajian keislaman. Dibawah bimbingannya misalnya Robert of Ketton mulai menerjemahkan teks alQur'an dan Hadits, sejarah Nabi Muhammad dan manuskrip Arab lainnya. Salah satu tokoh yang muncul pada periode ini adalah St Thomas Aquinas, yang tidak mengelompokkan penganut Islam sebagai kelompok Murtad (Heresy) tetapi mengategorikan ke dalam kelompok Kafir (Unbelief), sebuah sebutan yang cukup menyakitkan bagi umat Islam. Pada abad 12 hingga awal reformisme Eropa, pandangan kalangan Kristen terhadap Islam tetap menunjukkan keburukan Islam, meskipun kemudian terjadi perubahan terutama pada era reformasi Eropa yang memandang Islam secara lebih genuine, yang terlepas dari persepsi teologis yang memandang Islam sebagai agama yang menyimpang.

Ketiga, memasuki abad ke 13 perhatian kalangan Kristen mulai mengalami perubahan dan menemui dimensi lain dari peradaban Islam, hal ini terlihat dari perhatian mereka terhadap karyakarya saintifik Islam yang mulai diterjemahkan dan disirkulasikan secara luas di kalangan bangsa Eropa. Karya filosof Ibnu Sina (w. 1037) adalah diantara karya-karya yang menampilkan dimensi filosofis dan saintifik yang menjadi rujukan dalam kajian-kajian di Eropa. Hingga memasuki abad ke 16 pengaruh reformasi Eropa begitu kuatnya sehingga masalah-masalah teologis Islam tidak menjadi bahan yang dipersoalkan dengan menyalahkan agama ini, tetapi menjadi argumen untuk menyalahkan internal gereja. Tokoh gerakan reformisme gereja Protestan Marthin Luther misalnya memang menyudutkan Islam dan kekuasaan Bani Usmaniyah sebagai gerakan pengacau anti-Kristen. Akan tetapi diakui bahwa gerakan itu adalah bukanlah pengacau sebenarnya. Kesimpulan Marthin Luther, "Paus dan pasukannya Turki adalah musuh utama bagi Kristen dan Gereja Suci, dan jika pasukan Turki menjadi badan dari gerkan anti-Kristen maka Paus adalah kepalannya". (Edward W Said, 2010)

Islamic Studies yang dikembangkan kemudian didominasi oleh para orientalis dengan mengembangkan pendekatan-pendekatan sintetis dari berbagai disiplin dalam tradisi akademik Barat sejak abad ke 18 hingga awal abad ke 20. Untuk tujuan tersebut orientalisme kemudian dibangun dengan mengembangkan bahasa dan peradaban baik di Asia maupun di Afrika, terutama yang berkaitan dengan penyebaran dan pengaruh agama Islam. Tradisi philologis mulai dikembangkan melalui kerja intensif karena dianggap sebagai instrumen yang sangat penting dan merupakan ilmu kebudayaan umat manusia. Karya orientalis yang muncul antara lain Ecole des Langues Oreintal Vivantes di Paris tahun 1795, kemudian Description de I'Egypte, sebuah karya yang terdiri dari 23 jilid, bersisi tentang pedoman dasar yang sistematik untuk kajian sejarah dan kebudayaan bangsa-bangsa Muslim. Tokoh-tokoh lain dalam oreintalisme yang khusus mengkaji Islamic Studies antara lain Armand Pierre Caussin de Perceval (1795-1871), Etinne Quatremere (1782-1857), Leone Caetani (1869-1935), kemudian muncul beberapa jurnal yang dianggap sangat membantu pengembangan orientalisme seperti jurnal The Jounal of Royal Asaiatic Society (1834) dan Zeitschrif fur Deutsche Morgenlandische Gesellscahft (1845), dalam bahasa Jerman. (Mohammed Arkoun, 1994)

Memasuki paruh pertama abad ke 20 mulai muncul tokoh-tokoh kunci yang terkenal dalam Oriental Studies yang mengkaji Islam dalam berbagai aspeknya, "agama dan sejarah peradaban Islam", antara lain Ignaz Goldziher (1850-1921) menulis Vorlesungen (1910), 
Cristian Snouck Hurgronje (1857-1936), Carl Brockelmann (1868-1956), Carl Heinrich Becker (1876-1933), Duncan Black Mac Donald (18921925) menulis The Develompment of Muslim Theology Yurisprudence, and Constitutional Theory (1903),

Louis Massignon (1883-1962) yang menjadi redaktur utama jurnal Revues des Etudes Islamiques. Kajian oriental studi selanjutnya berkembang menjadi studi kawasan (area studies), kususnya Kajian Kawasan Timur Tengah (Midle Eastren Studies), yang populer setelah perang dunia kedua, meskipun warisan kajian philologis tetap mendominasi, disamping kajian kawasan yang menjadi instrumen penting dalam studi oreintalisme. Tokoh-tokoh orientalis yang pada periode ini antara lain adalah Claude Cahen (1909-1991), Phillip K Hitti (1886-1974), HAR Gibb (1895-1971), Gutave E von Grenebaum (1909-1972), dan Giorgio Levi Della Vida (18861974), AJ Wensicnk yang menulis The Muslim Creed dan Mu'jam al-Mufahras li alFadz al-Hadits, Wellhausen, Margoulioth, Noldeke, Lammens, Nicholson, Lyall, W. Montgomery Watt dan lainlain. (Kazuo Shimogaki, 2012)

Studi tentang Ketimuran atau Timur (Orient/Oriental) telah menjadi bahasan yang menarik di kalangan intelektulisme Barat, karena kawasan Timur sebagai representasi kawasan geografis yang mempunyai ciri khas di bandingkan dengan Barat, sehingga para spesialis di kawasan ini sebagian besar berasal dari Eropa atau Barat melakukan tugas-tugas mereka memperlakukan Timur sedemikian rupa. Tugas ini muncul karena pada saatnya, profesi mereka sebagai orientalis akan menuntut mereka menyajikan citra-citra Timur, pengetahuan mengenai Timur dan wawasan mendalam terhadap Timur kepada masyarakat mereka di Eropa. Misi para orientalis dalam menyajikan data berupa fenomena tentang Timur, menurut Edward W. Said berupaya menjelaskan secara obyektif tentang beberapa fakta. Pertama, representasi Timur yang menampakkan jejak-jejak mereka sendiri. Kedua, representasi Timur yang bisa menjelaskan konsepsi mereka mengenai bagaimana Timur bisa menjadi atau seharusnya menjadi. Ketiga, representasi Timur yang bisa memberikan apa yang tampak paling diperlukan oleh wacana orientalisme pada saat itu. Keempat, representasi Timur yang bisa menanggapi tuntutan-tuntutan budaya, profesional, masalah politik ekonomi tertentu pada zamannya.

Orientasi studi ketimuran (orientalisme modern) berkembang tidak hanya menyelidiki bahasa Timur, tetapi dalam fakta dan realitasnya juga lebih banyak melakukan studi terhadap agama Islam sebagai agama mayoritas bangsa Timur, melalui bidang Islamic Studies, di samping melakukan studi terhadap agama lainnya seperti Budha dan Hindu, serta agama-agama primitif bangsa Asia dan Eropa. Islamic Studies itu sendiri kemudian berkembang dan melibatkan berbagai cendekiawan dari berbagai latar belakang keilmuwan, dan dari beragam latar belakang kebangsaan. Pada awalnya obyek Islamic Studies hanya didominasi oleh kalangan cendekiawan dari Barat (Eropa dan Amerika Serikat), pada perkembangan lebih lanjut banyak orang-orang Asia termasuk warga negara Jepang yang menjadi pakar-pakar Islamic Studies seperti Sachiko Murata dalam karyanya The Tao of Islam: A Source on Gender Relationship in Islamic Thougth. Dan termasuk sebagian para cendekiawan dari Afrika, walaupun mereka tidak semuanya beragama Islam. Tokoh-tokoh yang dianggap representasi dari cendekiawan yang banyak menghasilkan karya-karya di bidang Islamic Studies, misalnya Mohammad Arkoun dalam bukunya Rethinking Islam, Hasan Hanafi, yang terkenal sebagai tokoh "Kiri Islam", seperti digambarkan oleh Kazuo Shimogaki dalam karyanya Beetwen Modernity and Pots Modernity The Islamic Left and Dr. Hassan Hanafi's Thought: A Critical Reading. Dalam buku yang lainnya Hassan Hanafi memperkenalkan sebuah gagasan tentang sikap terhadap tradisi yang dimiliki umat Islam yang berjudul Min al-Aqîdah ila al-Tsaurah al-Muqaddimah al-Nazāriyah yang diterjemahkan dalam bahasa Indonesia menjadi "Dari Aqidah Ke Revolusi; Sikap Kita terhadap Tradisi Lama". Kemudian pakar lainnya, Abdullahi Ahmed AnNaim, dalam bukunya Toward and Islamic Reformation: Civil Liberties, Human Right and International Law, yang telah diterjemahkan dalam bahasa Indonesia menjadi "Dekonstruksi Syari'ah: Wacana Kebebasan Sipil, Hak Asasi Manusia dan Hubungan Internasional dalam Islam", dan Nasr Hamid Abu Zaid, dalam bukunya An-Nashs, as-Sulthah, al-Hakîkah, dan telah diterjemahkan dalam bahasa Indonesia, menjadi "Teks Otoritas Kebenaran" oleh LKiS, dan lain sebagainya. (Hassan Hanafi, 2003)

Dalam perkembangan selanjutnya Islamic Studies berkembang menjadi studi kawasan, dan memunculkan beberapa cendekiawan yang hanya meneliti tentang kawasan tertentu berkaitan dengan sejarah bangsa atau negara di kawasan Timur. Beberapa tokoh yang "ahli Timur" sesungguhnya telah dirintis misalnya C. Snouk Hurgronje, yang ahli tentang Islam di Indonesia (Hindia-Belanda), kemudian setelah itu muncul peneliti-peneliti Barat terhadap budaya dan 
agama di Indonesia misalnya William Hefner yang meneliti tentang agama Suku Tengger di daerah Tengger Jawa Timur, Clifford Gerzt yang menghasilkan karya yang fenomenal, The Religion of Java (Agama Jawa) yang berhasil memtakan relasi antara tiga kelompok sosial di Jawa yakni kelompok "Abangan", "Santri" dan "Priyayi", dan menjadi bahan referensi utama dalam penelitian tentang Indonesia di masa selanjutnya, bahkan sebagian mereka terkenal sebagai ahli tentang Indonesia dengan sebutan pakar "Indonesianis"i.

Amin Abdullah memandang Islamic Studies merupakan sebuah bangunan keilmuan, yang memiliki kajian, metodologi, pendekatan dan kerangka teori, maka seperti halnya ilmu-ilmu yag lain, ia mestinya juga memiliki pembahsan tentang filsafat keilmuannya. Seperti halnya ilmuilmu keislaman yang mempunyai the philosophy of science, ilmu-ilmu sosial memiliki the philosophy of social sciencees, ilmu-ilmu keislaman tentunya juga mempunyai the philosophy of islamic sciences. Perkembangan Islamic Studies di Indonesia tidak dapat dilepaskan dari kajian Islam dilembaga-lembaga pendidikan tinggi, khususnya intitusi pendidikan tinggi agama Islam. Kajian keislaman di perguruan tinggi Islam sudah menjadi ciri khas yang menguatkan akar dan eksistensi kelembagaan pendidikan tinggi Islam baik yang dikelola oleh pemerintah maupun swasta. Islamic studies menjadi kebutuhan yang mendasar dalam rangka memperdalam kajian terhadap ajaran agama Islam dari bergai aspeknya, fikih, kalam, filsafat, tasawuf, tafsir, hadits dan sebagainya. (Amin Abdullah, 2013)

.Paling tidak, Islamic Studies yang dikembangkan di beberapa perguruan tinggi Islam dirintis oleh beberapa tokoh intelektual Muslim yang berkecimpung dalam dunia pendidikan tinggi Islam di Indonesia sejak kemunculan Institut Agama Islam dan Univesitas yang dikelola oleh umat Islam. Dalam konteks praktis Islamic Studies yang diajarkan di beberapa perguruan tingggi Islam dapat dilihat dari beberapa buku yang dijadikan referensi pengkajian Islam di perguruan tinggi khususnya di IAIN dan Perguruan tinggi Umum lainnya.karya-karya yang menjadi referensi kajian Keislaman itu antara lain adalah buku karangan H.M. Rasjyidi yang berjudul Empat Kuliyah Agama Islam Pada Perguruan Tinggi, yang berisi tentang definisi Agama dan kajian Islam tentang berbagai agama yang ada di dunia, serta masalah filsafat dan teologi Islam. Kemudian buku yang berniansa kajian keislaman di Indonesia adalah buku Perbandingan Agama, yang ditulis oleh A. Mukti Ali yang berjudul IImu Perbandingan Agama di Indonesia, yang berisi tentang sejarah studi perbandingan agama dan kaintannya dengan studi orientalisme, pada akhirnya A. Mukti Ali menyimpulkan untuk mengimbangi studi orientalisme perlu dikembangkan studi Oksidentalisme (studi tentang dunia Barat). Mukti Ali, juga menulis tentang gerakan pembaruan pemikiran di India dan Pakistan, dan dibukukan dalam memperbanyak kajian tentang Islam secara global dan banyak dijadikan rujukan dalam studi Islam di perguruan tinggi Islam.

Sementara itu kajian tentang Islamic Studies di perguruan tinggi Islam terutama di IAIN dan perguruan tinggi umum di Indonesia, sesungguhnya mulai dikembangkan secara ekstensif oleh Harun Nasution, melalui buku-buku karangannya, antara lain Pembaruan dalam Islam Sejarah Pemikiran dan Gerakan, yang mengupas tentang sejarah perkembangan aliran-aliran modern dalam Islam, dan tokoh-tokoh gerakangerakan modernisasi dalam Islam yang berkembang di berbagai negara mulai dari Mesir, Turki dan Pakistan. Kemudian Harun Nasution juga mencoba menulis tentang masalah teologi dan perbedaan pandangan teologi dari berbagai aliran Kalam di dalam Islam, karya tersebut adalah Teologi Islam, Aliran-Aliran Sejarah Analisa Perbandingan yang diterbitkan oleh Universitas Indonesia Press (UI Press), dan buku ini menjadi referensi standar dalam mempelajari Kalam atau Teologi Islam pada IAIN-IAIN yang ada seluruh Indonesia. (Abdullahi Ahmed An-Naim, 2013)

Menurut M. Atho' Mudzhar, metodologi Studi Islam sebenarnya telah diajarkan sejak berdirinya IAIN, namun kajiannya masih terserak-serak dan belum diintegrasikan dengan konsep-konsep metodologi penelitian ilmiah kontemporer, temasuk metodologi penelitian sosial. Walaupun begitu menurut M. Ahto' Mudzhar, pada tahun 1980-an mulai dilakukan pengorganisasain metodologi studi Islam yang masih terserak itu, dan disusun dalam suatu Mata Kuliah yang bernama Dirasah Islamiyah (Islamic Studies), dan buku yang dipakai adalah buku karangan Prof. Harun Nasution, yaitu Islam Ditinjau dari Berbagai Aspeknya, dan buku Pembaruan dalam Islam Sejarah Pemikiran dan Gerakan. Kelebihan buku tersebut antara lain, pertama isinya memberikan gambaran yang utuh tentang studi Islam serta cabang-cabang ilmu yang dapat dikembangkan di dalamnya yaitu Islam ditinjau dari aspek sejarah, politik, filsafat, pranata dan sebagainya. Kemudian yang kedua, buku tersebut merupakan pengantar yang baik dari kajian studi Islam, serta menerangkan tentang ilmu yang dikembangkan oleh studi Islam itu tidak statis (mati) tetapi terus berkembang secara dinamis. (Nasr Hamid Abu Zaid, 2012) 
Perkenalan mata kuliah Dirasah Islamiyah kepada mahasiswa yang belajar di IAIN seluruh Indonesia, pada tahun 1980-1990 an, diajarkan sebagai mata kuliah wajib yang materinya ditulis oleh dosen-dosen Dirasah Islamiyah dalam bentuk Diktat Mata kuliah, bahkan sebagian menebitkan tulisannya dalam bentuk buku. Kemudian mata kuliah Dirasah Islamiyah diganti dengan MSI (Metodologi Studi Islam), yang pada prinsipnya materinya sama dengan Dirasah Islamiyah tetapi dengan berbagai penyempurnaan. Di samping mata kuliah Dirasah Islamiyah yang diajarkan pada jenjang sarjana Strata Satu (S1), yang kemudian diganti dengan MSI, sebenarnya sebagai sebuah pengantar Studi Islam, juga diberikan mata kulian AMDI (Aliran Modern Dalam Islam) yang berusaha membuka cakrawala pemikiran Islam yang modern bagi para mahasiswa yang sedang belajar di IAIN yang ada.

Pada saat yang sama gairah untuk melakukan studi Islam di Barat sangat digalakkan yang didukung sepenuhnya oleh sponsor Departemen Agama RI, setelah melakukan proses seleksi dalam program pembibitan para Calon Dosen (Cados), di seluruh Indonesia untuk belajar di negara-negara Barat, ke Amerika, Kanada, Jerman, Belanda, Inggris dan sebagainya. Sebenarnya program belajar di Barat, telah dirintis sejak zaman Menteri Agama RI, A. Mukti Ali dan mencapai puncaknya pada masa menteri Munawir Syadzali, yang juga mulai mengirimkan Cados bukan hanya ke Barat tetapi juga ke Timur Tengah. Oleh karena itu tidak heran pada era 1990 an banyak sekali perkembangan dinamika intelektualisme Muslim di Indonesia yang dimotori oleh sebagian besar para intelektual muslim alumni dari Barat, Timur Tengah, maupun alumni dalam negeri. Buku-buku karangan alumni Barat, Timur Tengah maupun intelektual alumni dalam negeri sendiri banyak bermunculan dan menulis gagasan pembaruan Islam. (H. M. Rasjidi, 1974) Karya-karya intelektual mereka banyak ditemukan di toko buku, misalnya buku karangan Nurcholish Madjid, Jalaludin Rahmat, Kuntowijoyo, Imaduddin Abdurrahim, Endang Syaifudin Ansari, Abdurrahman Wahid, Azyumardi Azra, Atho Mudzhar, Dien Syamsudin, Komarudin Hidayat, Amin Abdullah, dan lain sebagainya. Buku-buku tersebut pada umumnya menjadi bahan bacaan para mahasiswa yang sedang menimba ilmu di perguruan tinggi agama Islam, dalam rangka memperdalam Dirasah Islamiyah (Islamic Studies). Hal ini mengindikasikan adanya semangat untuk memperdalam kajian keislaman yang dilakukan oleh sebagian besar intelektual Muslim di Indonesia pada era tersebut. Gagasan segar dan kontroversial, pada waktu itu cukup mendapatkan respons yang luas di masyarakat terutama di kalangan akademisi, seperti halnya lontaran-Iontaran ide yang di kemukakan oleh tokoh-tokoh kontroversial semacam Abdurrahman Wahid dan Nurcholish Madjid (Cak Nur), selalu melahirkan pro dan kontra di masyarakat, meskipun pada akhirnya "mereda" dengan sendirinya. (A. Mukti Ali, 1988)

Secara akademis, Islamic Studies sebenarnya telah dijadikan sebagai materi inti dibeberapa perguruan tinggi, misalnya di Universitas al-Azhar yang menjadi imam bagi IAIN dari segi metodologi mendekati Islam, paling kurang pada awalnya, studi Islam telah berubah bentuk pengorganisasiannya yang hingga tahun 1961, praktis mempunyai fakultas-fakultas sebagaimana yang dimiliki IAIN, seperti Fakultas Ushuludin, Fakultas Fdakwah, Fakultas Tarbiyah, Fakultas Studi Islam dan Arab, Fakultas Bahasa Arab, dan Fakultas Hukum. Baru tahun 1961 dan seterusnya al-Azhar tidak membatasi diri pada Fakultas agama, tetapi juga membuka fakultas lainnya, seperti Fakultas Kedokteran, Fakultas Pertanian, Fakultas Ekonomi, Fakultas Sains dan Fakultas Teknik. Sementara itu di Indonesia fakultas agama Islam menjadi fakultas inti yang ada di IAIN antara lain Fakultas Tarbiyah, Fakultas Syariah, Fakultas Adab, Fakultas Ushuludin dan Fakultas Dakwah. Baru pada tahun 2002 perubahan status dari IAIN menjadi UIN yang diawali oleh UIN Syarif Hidasyatullah Jakarta, mulai dibuka fakultas-fakultas selain fakultas agama, seperti Fakultas Ekonomi, Fakultas Sains, Fakultas Kedokteran dan sebagainya. Model ini kemudian diikuti oleh perubahan status kelembagaan IAIN seluruh Indonesia. Walaupun begitu perubahan tersebut tidak mengurangi posisi IAIN ataupun UIN menjadi sentral kajian Islam (Islamic Studies). Kalau dibandingkan dengan Mesir tampaknya agak jauh rentang perubahan tersebut, di Al-Azhar perubahan dan penambahan fakultas sudah dimulai tahun 1961, sedangkan perubahan kelambagaan IAIN menjadi UIN baru terjadi pada tahun 2002. (Harun Nasution, 1996)

Atho' Mudzhar mencoba mendeskripsikan Islamic Studies secara faktual juga dipelajari diberbagai negara-negara non-Muslim, di sini bisa dilacak misalnya; Pertama, di Chicago University, Studi Islam (Islamic Studies) menekankan pada pemikiran Islam, bahasa Arab, naskah klasik dan bahasa-bahasa Islam non-Arab. Secara organisatoris studi itu berada di bawah Pusat Studi Timur Tengah dan Jurusan Bahasa dan Kebudayaan Timur Dekat. Di Amerika, studi-studi Islam pada umumnya memang menekankan pada studi sejarah Islam, bahasa-bahasa Islam selain 
bahasa Arab, sastra dan ilmu-ilmu sosial, berada di bawah Pusat Studi Timur Tengah atau Timur Dekat. Kedua, di Universitas California (UCLA), Islamic Studies dibagi menjadi empat komponen, antara lain; mengenai doktrin dan sejarah Islam, termasuk sejarah pemikiran Islam, kemudian bahasa Arab termasuk teks-teks klasik mengenai sejarah, hukum dan lain-lain, kemudian bahasabahasa non-Arab yang muslim seperti bahasa Turki, Urdu dan Persia, sebagai bahasa yang dianggap turut melahirkan peradaban Islam, selanjutnya kajian tentang ilmu-ilmu sosial, sejarah, bahasa Arab, bahasa-bahasa Islam, sosiologi, selainitu ada keawajiban menguasai secara pasif satu atau dua bahasa Eropa. Ketiga, di London Inggris, Islamic Studies (Studi Islam) digabungkan dalam School of Oriental and Africa Studies, fakultas mengenai studi ketimuran dan Afrika, yang mempunyai berbagai jurusan Bahasa dan Kebudayaan Asia dan Afrika. Keempat, di Kanada Islamic Studies, bertujuan antara lain untuk menekuni kajian budaya dan peradaban Islam dari zaman Nabi Muhammad hingga masa kontemporer, memahami ajaran Islam dan masyarakat Muslim di seluruh dunia, dan mempelajari berbagai bahasa Muslim seperti bahasa Persia, Urdu dan Turki. Kelima, di Belanda, Islamic Studies menurut catatan sejarah sampai setelah perang Dunia II, studi Islam masih merupakan refleksi dari akar anggapan seperti Islam bermusuhan dengan Kristen, dan pandangan bahwa Islam sebagai agama yang tidak patut dianut. Belakangan ada sikap yang lebih objektif, kajian-kajian Islam lebih menekankan pada kajian Islam di Indonesia, dan daerah-daerah tertentu, kurang menekankan pada aspek sejarah Islam itu sendiri. Di Universitas-universitas tersebut kebanyakan para intelektual Muslim Indonesia memperdalam studi mereka tentang Islamic Studies, dan para alumnusnya setelah kembali ke tanah air mengajar di beberapa perguruan tinggi Islam sebagai tenaga akademisi ataupun sebagai pengelola lembag-lembaga pendidikan tinggi Islam, terutama di IAIN, STAIN dan UIN. (Ahmad Muthohar, 2013)

Sama halnya di Indonesia Islamic Studies menjadi bagian integral dari pengajaran Islam di negara-negara Muslim, seperti Pertama, di Iran, Universitas Teheran terdapat satu Fakultas (Kullliyat Ilahiyat), dan menyimpan naskahnaskah kuno yang ditulis oleh para pemikir klasik dan ditulis dalam bahasa Persia. Kedua, di Universitas Damaskus, Syiria, Studi Islam ditampung dalam Kulliyat As-Syari'ah (Fakultas Syariah), yang didalamnya terdapat program studi ushuluddin, tasawuf, tafsir, dan sejenisnya.
Ketiga, di Universitas Aligarch India, Studi Islam dibagi menjadi dua. Islam sebagai doktrin dikaji dalam Fakultas Ushuludin yang mempunyai dua jurusan; Jurusan Madzhab Ahlu Sunnah dan Syi'ah. Sedangkan Islam sebagai Sejarah dikaji di Fakultas Humaniora dalam jurusan "Islamic Studies" yang berdiri sejajar dengan jurusan Politik, Sejarah dan lain-lainnya. Di Jamiah Millia Islamia, Fakultas Humaniora, bersama dengan Arabic Studies, Persian Studies, dan Political Science. Keempat, di Universitas Islam Internasional Malaysia, program studi Islam berada di bawah "Kulliyah of Revealed Knowledge and Human Sciences" . Selain jurusan Kewahyuan dan Warisan Islam, di dalam fakultas ini juga ada jurusan-jurusan psikologi, ekonomi dan sebagainya. (M. Atho Mudzhar, 1998)

Di Indonesia studi Islam (Islamic Studies) menjadi semacam icon atau karakter utama bagi corak pembelajaran di IAIN atau perguruan tinggi agama Islam swasta. Secara serius pendidikan Program pascasarjana di IAIN pada awalnya didesain dengan kurikulum Pengkajian Islam (Islamic Studies), yang dimotori oleh rektor IAIN Jakarta pada waktu itu Prof. Harun Nasution, kemudian diikuti oleh program Pascasarjana lainnya. Dalam silabus pembelajarannya, materi yang diajarkan anatara lain sejarah kebudayaan dan peradaban Islam, sejarah intelektual dan filsafat Islam, tasawuf Islam, filsafat Ilmu, juga bahasa Asing selain bahasa Arab misalnya bahasa Urdu, untuk memperdalam Islam di kawasan Asia. Hingga sekarang tampaknya Islamic Studies tetap menjadi materi yang dijadikan sebagai indentitas studi Islam di IAIN bahkan ketika sudah berubah menjadi UIN. Perkembangan kajian Islam juga merambah pada semangat menulis sebagai ekspresi intelektual Islam di Indonesia yang diterbitkan dalam beberapa Jurnal Islamic Studies, misalnya Jurnal Ulumul Qur'an yang menjadi jurnal yang otoritatif berisi tentang berbagai kajian Islam yang ditulis oleh beberapa cendekiwan Muslim pada era 1980-1990an, akan tetapi keberadaan jurnal ini kemudian menjadi sangat jarang dan langka terutama pasca reformasi. Kemudian jurnal lainnya yang bisa dianggap mempunyai reputasi yang baik adalah Jurnal Studia Islamika, yang diterbitkan oleh PPIM (Pusat Pengkajian Islam dan Masyarakat) UIN Syarif Hidayatullah Jakarta. Jurnal ini sangat kredibel dan berisi tentang berbagai artikel Islamic Studies dalam beberap bahasa asing yakni bahasa Inggris, Arab dan Indonesia. Kemudian disusul oleh jurnal-jurnal lainnya yang diterbitkan oleh IAIN maupun UIN lainnya yang belakangan sudah banyak yang terakreditasi. Hampir semua jurnal yang ada menyajikan tentang kajian keislaman 
dalam berbagai aspeknya, antara lain filsafat, pemikiran modern Islam, tasawuf, etika, tafsir, hadits, hukum Islam (syariah), pendidikan Islam, dan lain-lainnya yang ditulis sebagian besar adalah dosen-dosen PTAIN dan PTAIS. (Helmi Uman, 2013)

\section{Penutup}

Pengkajian Islam (Islamic Studies) atau studi Islam mempunyai catatan sejarah yang cukup panjang, ada yang menengarai bahwa studi Orientalisme tidak bisa dipisahkan dengan disiplin Islami Studies. Karena dalam konteks sejarahnya Islamic Studies memang menjadi salah satu bahan kajian studi ketimuran (orientalisme modern). Meskipun demikian dalam perkembangan selanjutnya Islamic Studies telah mnjelma menjadi disiplin ilmu yang bukan hanya secara akademik dipelajari di perguruan tinggi di Barat tetapi, ia juga dipelajari di berbagai perguruan tinggi di negara-negara Muslim di dunia. Walaupun pada awalnya studi orientalisme berusaha mempelajari semua aspek dari dunia Timur, akan tetapi secara faktual, karena mayoritas dari bangsa Timur (Asia dan Afrika) kebanyakan beragam Islam, maka kajian orientalisme modern lebih banyak menyoroti perkembangan agama Islam dan umat Islam dalam segala dimensinya, sperti dimensi sejarah, politik, filsafat, budaya, ekonomi, pemikiran, dan lain sebagainya.

Pengkajian Islam (Islamic Studies) secara metodologis juga dijadikan sebagai materi pembelajaran di berbagai perguruan tinggi Islam di Indonesia, yang menyajikan materi Dirasah Islamiyah sebagai materi wajib yang diajarkan di IAIN, STAIN, dan UIN, meskipun sejak tahun 1997 terjadi perubahan namanya menjadi MSI (Metodologi Studi Islam), tetapi materinya tidak banyak berubah yakni memberikan bekal kepada mahasiswa untuk memperdalam wawasan tentang sejarah peradaban dan kebudayan Islam, filsafat, tasawuf, fiqih, kalam, dan etika Islam. Pengembangan materi Islamic Studies di Indonesia di PTAIN tersebut berkat jasa-jasa dari para cendekiawan Muslim yang pernah secara geneologis pemikiran berasal dari universitasuniversitas di Barat, karena pada umumnya mereka adalah alumni dari program Islamic Studies di negara-negara tersebut [.].

\section{Referensi}

Abdullah, M. Amin., 2006. Islamic Studies di Perguruan Tinggi, Pendekatan IntegratifInterkonektif, Yogyakarta: Putaka Pelajar.

Ali, A Mukti., 1988. Ilmu Perbandingan Agama di Indonesia, Yogyakarta: IAIN Sunan Kalijaga Press.

An-Naim, Abdullahi Ahmed., 2011. Dekonstruksi Syari'ah, Yogyakarta: LKiS.

Arkoun, Mohammed. 1994. Rethinking Islam Common Question Uncommon Answers, Colorado: Westview Press.

Geertz, Clifford. 2013. Agama Jawa, Abangan Santri Priyayi dalam Kebudayaan Jawa, Depok: Komunitas Bambu.

Hanafi, Hassan. 2003. Dari Akidah ke Revolusi, Jakarta: Paramadina.

Hourani, Abert. 1990. Europe and Midle East, London; The Macmillan Press.

Martin, Richard C. 1995. "Islamic Studies: History of The Field", dalam The Oxford Encyclopedia of Modern Islamic World, Vol. 2 Oxford: Oxford University Press.

Mochtar, Affandi., Membedah Diskursus Pendidikan Islam, Jakarta: Kalimah, 2001.

Mudzhar, M. Atho. 1998. Pendekatan Studi Islam dalam Teori dan Praktek, Yogyakarta; Pustaka Pelajar.

Muhaimin, dkk, 1994. Dimensi-Dimensi Studi Islam, Surabaya: Abditama.

Mukhlas, Moh. 2006. Urgensi Integrasi Sains dan Agama. Al-Tahrir, 6(1), Januari.

Murata, Sachiko. 2000. The Tao of Islam, Bandung; Mizan.

Muthohar, Ahmad. 2013. Urgensi Pendidikan Islam. Cendekia, 11(1).

Nasution, Harun. 1996. Pembaruan dalam Islam Sejarah Pemikiran dan Gerakan Jakarta; Bulan Bintang.

1980.Teologi Islam. Aliran-Aliran Sejarah Analisa Perbandingan, Jakarta; UI Press.

, 1995 Falsafat dan Mistisisme dalam Islam, Jakarta; Bulan Bintang.

1980. Islam ditinjau Dari Berbagai Aspeknya, jilid 1 dan 2, Jakarta; UI Press.

Rasjidi, H.M., 1974. Empat Kuliyah Agama Islam Pada Perguruan Tinggi, Jakarta: Bulan Bintang.

Said, Edward W. 2010. Orientalisme, Menggungat Hegemoni Barat dan Menundukkan Timur Sebagai Subjek, Yogyakarta: Pustaka Pelajar.

Shimogaki, Kazuo. 2012. Kiri Islam antara Modernisme dan Post-Modernisme, Telaah Kritis Pemikiran Hassan Hanafi, Yogyakarta: LkiS.

Uman, Pemikiran Islam. 2013. Teosofi, 3(2) Desember.

Zaid, Nasr Hamid Abu., 2012. Teks Otoritas Kebenaran, Yogyakarta; Lkis. 